\title{
Migration ecology of western gray catbirds
}

\author{
Kristen A. Mancuso ${ }^{1 *} \mathbb{D}$, Megan A. Fylling ${ }^{2}$, Christine A. Bishop 3 , Karen E. Hodges ${ }^{1}$,
}

Michael B. Lancaster ${ }^{4}$ and Katharine R. Stone ${ }^{5}$

\begin{abstract}
Background: For many songbirds in North America, we lack movement details about the full annual cycle, notably outside the breeding season. Understanding how populations are linked spatially between breeding and overwintering periods (migratory connectivity) is crucial to songbird conservation and management. We assessed migratory connectivity for 2 breeding populations of Gray Catbirds (Dumetella carolinensis) west of and within the Rocky Mountains by determining migration routes, stopover sites, and overwintering locations. Additionally, we compared apparent annual survivorship for both populations.
\end{abstract}

Methods: We deployed 39 archival light-level geolocators and 21 Global Positioning System (GPS) tags on catbirds in the South Okanagan Valley, British Columbia, Canada, and 32 geolocators and 52 GPS tags in the Bitterroot River Valley, Montana, USA. These devices allowed us to determine migration routes, stopover sites, overwintering locations, and migratory connectivity. Migratory connectivity was quantified using Mantel's correlation. We used mark-recapture of colour banded catbirds in both sites to estimate apparent annual survivorship.

Results: We retrieved 6 geolocators and 19 GPS tags with usable data. Gray Catbirds from both populations passed through the Rocky Mountains eastward before heading south towards their overwintering locations in northeastern Mexico and Texas. Stopover sites during fall migration occurred primarily in Montana, Kansas, Oklahoma, and Arkansas. Overwintering locations spanned Texas and 5 states in northeastern Mexico. Individual catbirds used up to 4 distinct sites during the overwintering period. Catbirds separated by almost $500 \mathrm{~km}$ during the breeding season overlapped during the non-breeding season, suggesting weak migratory connectivity among western populations (Mantel's correlation $=0.013, P$-value $=0.41$ ). Catbird apparent annual survivorship estimates were higher in British Columbia ( $0.61 \pm 0.06$ females; $0.64 \pm 0.05$ males) than in Montana ( $0.34 \pm 0.05$ females; $0.43 \pm 0.04$ males), though the main driver of these differences remain unclear.

Conclusions: Our results provide high precision geographic details during the breeding, migration, and overwintering phases of the annual cycle for western Gray Catbirds. Notably, we found that western catbirds followed the Central Flyway as opposed to the Pacific Flyway. We document that catbirds used multiple sites over winter, contrary to the popular belief that this phase of the annual cycle is stationary for most songbirds.

Keywords: Dumetella carolinensis, Full annual cycle, Migration, Migratory connectivity, GPS tracking

\footnotetext{
* Correspondence: kmancuso88@gmail.com

'Department of Biology, University of British Columbia Okanagan, Kelowna, British Columbia, Canada

Full list of author information is available at the end of the article
}

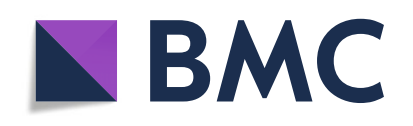

(- The Author(s). 2021 Open Access This article is licensed under a Creative Commons Attribution 4.0 International License, which permits use, sharing, adaptation, distribution and reproduction in any medium or format, as long as you give appropriate credit to the original author(s) and the source, provide a link to the Creative Commons licence, and indicate if changes were made. The images or other third party material in this article are included in the article's Creative Commons licence, unless indicated otherwise in a credit line to the material. If material is not included in the article's Creative Commons licence and your intended use is not permitted by statutory regulation or exceeds the permitted use, you will need to obtain permission directly from the copyright holder. To view a copy of this licence, visit http://creativecommons.org/licenses/by/4.0/. The Creative Commons Public Domain Dedication waiver (http://creativecommons.org/publicdomain/zero/1.0/) applies to the data made available in this article, unless otherwise stated in a credit line to the data. 


\section{Background}

The decline of North American songbirds is a conservation concern in the Anthropocene [1, 2]. There are major knowledge gaps in the ecology of most migratory bird species, with deficits evident especially during migration and winter because most research is focused on breeding birds [2-5]. The link through space and time between breeding and overwintering periods is important to address, in part because the effects in one season can influence events in another season, such as habitat quality influencing body condition and migration timing $[5,6]$. The full annual cycle of migrant songbirds generally includes breeding, fall migration, overwintering, and spring migration. To identify potential threats throughout the annual cycle, it is important to understand where, when, and how long a bird is present at each stage of the cycle [7, 8].

Conservation and management efforts for songbirds require an understanding of how populations are geographically linked through different phases of the annual cycle - a concept termed migratory connectivity [7, 9]. Individuals from populations of species with strong migratory connectivity show minimal geographic spread and little overlap with other populations through different phases of the annual cycle, whereas individuals from populations of species with weak migratory connectivity show greater geographic spread and may co-occur with individuals from different populations [7, 9]. Consequently, a threat on the overwintering grounds may have diffuse effects among multiple populations if weak migratory connectivity exists $[7,10]$. However, it may be more challenging to implement effective conservation strategies across the annual cycle for populations with weak migratory connectivity.

In addition to studying population-level characteristics of a species, apparent annual survivorship is a valuable demographic rate because it can indicate the health of a population, life cycle stages at risk, and identify highquality habitat $[11,12]$. Survivorship is sensitive to short-term and local environmental changes and, therefore, can help elucidate the underlying mechanisms to changes in population size $[11,12]$. However, robust annual survivorship estimates can be challenging to obtain as they require multiple years of data on marked individuals.

In this study, we examined the migration behaviour and estimated apparent annual survivorship of Gray Catbirds (Dumetella carolinensis) breeding west of and within the Rocky Mountain Range. Gray Catbirds are the only species within the Mimidae family whose migratory behaviour has been studied in detail but only in the eastern portion of its extensive North American range [13]. The known overwintering range of Gray Catbirds includes Florida, southeastern Texas, southeastern
Louisiana, eastern Mexico, and Central America [14]. In the eastern and central portion of the breeding range, Ryder et al. [13] found catbirds breeding in the midAtlantic overwintered in Cuba and Florida, and those breeding in the Midwest overwintered in Central America. Likewise, stopover ecology is limited to eastern populations; one mark-recapture study in coastal Alabama during fall migration reported adult catbirds stayed on average for 4.1 days before departure [15].

The migration ecology of western Gray Catbirds, including how they travel through or around the Rocky Mountain Range, remains unexplored. Most migratory birds breeding west of the mountains migrate using the Pacific Flyway, whereas most birds east of the mountains follow the Central Flyway [16-19]. However, studies from central and coastal British Columbia tracked breeding Veeries (Catharus fuscescens) and Swainson's Thrushes (C. ustulatus) across the Rocky Mountains to the Central Flyway towards overwintering sites in South America [20-22]. In 1964, it was postulated that western Gray Catbirds may migrate east before heading south, implying that these birds have to cross the Rocky Mountains [23]. Similarly, the analyses of stable hydrogen isotope ratios of catbird feathers linked overwintering birds in Mexico to inferred breeding sites located in the northwestern part of their breeding range [24].

The goals of our research on Gray Catbirds were to: (1) track migration routes; (2) identify stopover sites; (3) determine overwintering locations; (4) assess migratory connectivity; and (5) compare apparent survivorship for populations breeding in western Montana, USA, and southern British Columbia, Canada. Our research will verify whether western Gray Catbirds migrate using the Pacific Flyway or the Central Flyway. In addition, we will advance our understanding of the full annual cycle of western catbird populations and their migration ecology which may help ensure this species remains abundant on the landscape.

\section{Methods}

\section{Study areas}

We examined breeding Gray Catbirds in two locations: (1) the South Okanagan Valley, British Columbia, Canada $\left(49.200^{\circ} \mathrm{N}, 119.552^{\circ} \mathrm{W}\right)$, and (2) the Bitterroot River Valley, Montana, USA $\left(46.668^{\circ} \mathrm{N}, 114.023^{\circ} \mathrm{W}\right)$. These two study areas were $495 \mathrm{~km}$ apart, with the British Columbia population occurring west of the Rocky Mountains and the Montana population occurring within the Rocky Mountains. Catbirds were locally abundant in both study sites.

\section{Tracking devices}

Gray Catbirds were captured in mist-nets passively or with the aid of call-playback in the breeding seasons 
from 2013 to 2018. Each bird was given a standard USGS band and a unique combination of colour-bands to aid in future identification. Birds were aged and sexed according to Pyle (1997) [25]. Adult male and female catbirds were outfitted with an M-Series light-level geolocator, Lotek, Newmarket, Canada (mass between 0.3$1.0 \mathrm{~g}$, hereafter "geolocator") or PinPoint GPS tag, Lotek, Newmarket, Canada, (mass $1.0 \mathrm{~g}$, hereafter "GPS tag" $[26,27])$. Geolocators were used only to infer general movement patterns whereas GPS tags were used for movement patterns plus quantitative analyses.

Tracking devices were fitted onto birds by creating a leg-loop harness which allowed the device to sit on the lower back of the bird, an optimal position for sunlight and satellite communication [28]. The harness was made of Stretch Magic jewelry cord manufactured by Pepperell Braiding Company, MA. Stretch Magic is an elastic-like, transparent, monofilament made of polyurethane and polyester and was ideal for accommodating fluctuations in size throughout the year. The harnesses were closed either by using a crimp bead or melting with a soldering iron, allowing harnesses to be custom fit to birds of varying sizes. Throughout the project, we checked recaptured birds for any sign of wear, abrasion, or feather loss and found minimal undesirable effects, however, some birds had evidence of light chafing on their thighs. Harnesses were durable and we had no instances of birds losing their geolocators or GPS tags with this method. This technique was adopted from other researchers who used the method successfully for attaching geolocators to songbirds [29, 30].

The average mass of Gray Catbirds was $36.3 \mathrm{~g}$, therefore, tracking devices were $<3 \%$ of body mass, which is the preferred maximum for tracking birds and within the $<5 \%$ recommendation by animal care committee standards [31, 32]. Due to the small size of the devices, the number of GPS fixes were limited, with up to 8 fixes advertised for PinPoint- 8 tags, up 10 fixes advertised for PinPoint-10 tags, and up to 80 fixes advertised for Swift PinPoint-10 tags [33]. Devices were retrieved in subsequent breeding seasons by targeting individuals identified by their unique colour-band combination. Captured birds had the harness and device removed then released unharmed. We deployed 39 geolocators and 21 GPS tags in British Columbia, and 32 geolocators and 52 GPS devices in Montana.

The average accuracy ( \pm standard deviation) of the MSeries geolocator is $185( \pm 115) \mathrm{km}$, but many factors may affect the accuracy of geolocators, including shading, clouds, sensor degradation, and artificial lights [34]. The shrubby riparian habitat inhabited by Gray Catbirds may be an additional source of shade and further limit geolocator accuracy. The accuracy of GPS tags varies depending on the number of satellites available during a scheduled fix, however, in all cases should be better than $300 \mathrm{~m}$ [33]. We tested the GPS tags before deployment in British Columbia at a stationary location and found that $90 \%$ of the points were within $100 \mathrm{~m}$ of the test location, and many within a few meters. GPS tags were pre-programmed to obtain GPS coordinates at specific dates, which varied by location and year but generally were 1-5 days apart during migration and 10-30 days apart during winter.

\section{Repeat tracking}

Three Montana birds were tracked in multiple years with separate devices. One female catbird was given a geolocator in 2012, another geolocator in 2013, and a GPS tag in 2014. One male catbird was given a geolocator in 2013 and a GPS tag in 2014. Another male catbird was given a GPS tag in 2016 and another GPS tag in 2017.

\section{Analyses of tracking devices}

Geolocator files (.lig) were downloaded and light data were processed using R ( $v$ 3.5.1 [35]). Methods for the analyses of the geolocators followed Lisovski et al. (2020) [36]. We used the GeoLight (v. 2.0.1 [37]), TwGeos (v.0.1.2 [38]), and adehabitatHR (v. 0.4.16 [39]) packages. Twilights were determined using the preprocessLight function in the TwGeos package using a threshold value of 0.5 because there did not appear to be any nighttime light interference. Twilights were edited using the twilightEdit function from the TwGeos package (with 'window' set to 4, 'outlier.mins' set to 45 , and 'stationary.mins' set to 25). Overwintering dates were defined as November 15 - March 1 to avoid the equinox by 3 weeks and to include times when birds would be on their wintering grounds [40]. The Hill-Ekstrom method was used to determine the sun elevation angle during winter months using the findHEZenith function from the TwGeos package $[41,42]$. The Hill-Ekstrom method determines the correct sun elevation angle for stationary periods at unknown locations by determining a sun elevation angle that minimizes variance in latitude estimates [43]. Winter latitude and longitude estimates were calculated using the coord function of Geolight. To summarize the overwintering locations used by Gray Catbirds, 50\% Kernel Density estimates were calculated from coordinates using the kerneluD function from the adehabitatHR package. A shapefile compatible with ArcMap 10.7.1 [44] was created by using the getverticeshr function.

The location coordinates from the GPS tags were vetted by removing points that had low accuracy, defined as those with dilution of precision values greater than 20 [33]. The remaining points were plotted using ArcMap 10.7.1. Points were connected to create migration 
tracks and to calculate distances, although we caution that these straight-line paths are our best approximation of migration route as the exact path is unknown. We defined stopover sites as locations with 2 or more consecutive fixes during migration outside of the mapped nonbreeding range in September and early October. GPS fixes were programmed to be taken between 1 and 5 days apart, therefore, the minimum stationary period during migration that we considered a stopover was 24 h. Overwintering locations were defined as the first stationary period of consecutive fixes in the known overwintering range. However, for the older generation GPS tags where 8 or fewer fixes were obtained, we assume that the points occurring from mid-October onwards correspond to overwintering locations, as most GPStagged birds from both sites had reached their overwintering locations by early October based on the later model Swift GPS tags. To visualize potential travel routes around or within the Rocky Mountains, tracks and points were overlaid on a 30 arc-second digital elevation model of North America in ArcMap 10.7.1 [44]. To better contextualize habitat and elevation at stopover locations and overwintering locations, we overlaid satellite imagery using ArcMap 10.7.1 for each catbird during stopovers and in the non-breeding period.

\section{Migratory connectivity}

Migratory connectivity was quantified with a Mantel's correlation $\left(\mathrm{r}_{\mathrm{M}}\right)$ which involves comparing two matrices and their random permutations [45]. A significant positive correlation in the distances between breeding individuals and overwintering individuals suggests strong migratory connectivity [46]. Our matrices included (1) the geographic distances between all individuals on the breeding ground and (2) the geographic distances between all individuals on the overwintering grounds. Because some catbirds moved around during the overwintering period and we did not have data for the full overwintering period for all birds, we used the first overwintering location for the second matrix. Note that only geographic locations from GPS tags were included in the distance matrices and not locations obtained by geolocators due to the inherent low precision associated with geolocators. Matrices were created using the r.dist.earth function of the fields package (v.9.8.6 [47]) in R. The Mantel correlation coefficient was calculated using the mantel.rtest function of the ade4 package (v.1.7.13 [48]). A $P$-value associated with the correlation coefficient was calculated based on 9999 random permutations. In addition to Mantel's correlation, we calculated the average pairwise distances between all individuals within the breeding and overwintering locations separately for Montana and British Columbia birds to quantify the geographic spread of each population.

\section{Apparent annual survivorship}

We included both recaptured and resighted birds in our apparent annual survivorship analyses. In British Columbia, the data set spanned 2015 to 2019 and a total of 537 birds were colour-banded. Two study sites in British Columbia were used and effort included (1) intermittent target and passive mist-netting in conjunction with deploying and retrieving tracking devices; and (2) a standardized approach. Target and passive netting involved setting up 1-8 nets from before sunrise to early afternoon at the latest and occurred intermittently $(\sim 1-$ 3 times a week) between May-August. Concurrently, 13 biologists searched for birds using binoculars and confirmed colour-band combinations using high-zoom digital cameras or binoculars. Effort was increased during the last year of the study in 2019, where at least 5 days a week, catbirds were resighted or recaptured from the end of May to early July. The standardized approach occurred once a week between May 1-September 15 using 10 mist-nets in a fixed location for $6 \mathrm{~h}$ and occurred in the first site only.

In Montana, the dataset spanned 2006 to 2018 and a total of 741 catbirds were colour-banded. Two study sites in Montana were used and effort included (1) intermittent target and passive mist-netting in conjunction with deploying and retrieving tracking devices; (2) a standardized approach, (3) intermittent banding for educational purposes ( 5 days total). Target and passive netting included 1-3 technicians working most weekdays between May 25-July 15 from sunrise to approximately 11:30 AM to resight and target net colour-banded catbirds between 2012 and 2018 at the first site only. Standardized MAPS banding efforts occurred from 2011 to 2018 at the first site and 2006-2018 at the second site and involved 10 mist nets open $6 \mathrm{~h}$ a day for 7 sample periods during the breeding season [49]. Educational banding occurred only at the second site.

Apparent annual survivorship was calculated using RMark (v. 2.2.7 [50]) in R. Cormack-Jolly-Seber models $[51,52]$ were used, which included the apparent annual survivorship $(\phi)$ and detection probability $(\mathrm{p})$ as model parameters. Assumptions of Cormack-Jolly-Seber models are that (1) every bird has the same probability of being recaptured/resighted at the next sampling period; (2) every bird has the same probability of surviving to the next sample period; (3) Colour-bands are not lost or missed, and; (4) sampling time is short (or instantaneous) relative to the interval in between sampling times. To assess the goodness-of-fit of our data to the assumptions of Cormack-Jolly-Seber models, we used the program RELEASE via RMark using the function 'release.gof'. Goodness-of-fit was assessed by examining the fit of the global model. Because we were comparing the fit of multiple models with varying parameters, we 
used the model with the highest number of parameters as the global model, which contained sex as a covariate. There was no evidence of a lack of fit of the global model to Cormack-Jolly-Seber model assumptions $\left(\chi^{2}=\right.$ 27.35, $\mathrm{df}=25, P$-value $=0.34$ ).

Birds of all ages (except nestlings) were used in the analyses. Sex was included as a covariate for both survivorship and detection. To account for potential local differences between sites within each study area, site was included as a covariate. Because the first encounter is likely to include young or transient birds who are more likely to permanently leave the study area through death or immigration and thereby have a lower apparent annual survivorship in this first year after being colour-banded, we included a time-sincemarking covariate where the first encounter is separated from subsequent encounters [53, 54]. Multiple models that contained different combinations of covariates were compared using an Akaike Information Criteria (AIC) approach adjusted for small sample sizes (Table 1, Burnham and Anderson 2002). We considered models with $\Delta \mathrm{AIC}_{\mathrm{c}}$ values of less than 2 to have substantial support [55]. We also calculated $\mathrm{AIC}_{\mathrm{c}}$ weight and considered any model with a weight of greater than 0.90 as a clear top model [55]. For all analyses, mean and standard error are reported unless otherwise noted.

\section{Results}

In British Columbia, the return rate of birds with geolocators was 8 out of 39 (20.5\%), and 7 geolocators were retrieved. The return rate of catbirds with GPS tags was 6 out of 20 (30.0\%), excluding one deceased catbird found in the same year of deployment. All 6 GPS tags were retrieved. We experienced poor performance in the geolocator technology. One geolocator had light data for only 2 months, but all other geolocators contained data for the full year. Light levels recorded on the geolocators were low and inconsistent, making the determinations on sunrises and sunsets spurious (an example of low-quality geolocator data can be found in additional file 1). All location estimates were severely outside known overwintering distributions (examples of erroneous location estimates can be found in additional file 1). All GPS tags contained data but fewer than the advertised maximum number of 80 fixes.

In Montana, the return rate of birds with geolocators was 10 out of 32 (31.3\%), and 6 geolocators were retrieved. The return rate of catbirds with GPS tags was 18 out of $52(34.6 \%)$, and 14 GPS tags were retrieved. All geolocators contained usable data, but 2 GPS tags did not contain usable data.

\section{Migration routes}

The migration route identified from GPS tags showed catbirds from Montana and British Columbia heading east across the Rocky Mountain Range, then south towards overwintering locations in Mexico and Texas (Fig. 1). While navigating the Rocky Mountain Range, Gray Catbirds from British Columbia appear to have traveled through lower elevation corridors; the elevation of points occurring within the Rocky Mountain Range were 1939, 849, 1020, 917, 497, 392, 662, 886, and $1034 \mathrm{~m}$ whereas the mountainous peaks within British Columbia, Washington, Idaho, and reach heights $>3000 \mathrm{~m}$ above sea level (Fig. 1). The fixes for Montana Gray Catbirds occurred too far east of the Rocky Mountain Range to assess their specific paths through the mountains.

In 5 cases from Montana, we have at least part of the spring migration route. These birds followed the same general routes in fall and spring (Fig. 2). Migration speed averaged $113 \mathrm{~km} /$ day and we saw no difference between spring and fall $(\mathrm{t}=-1.3, \mathrm{df}=10, P$-value $=0.24,95 \% \mathrm{CI}$ : -43.7, 12.2; Table 1). No spring migration data was available from British Columbia catbirds due to GPS tag battery exhaustion.

\section{Stopover sites}

We identified 20 fall stopover sites and one spring stopover site from our two catbird populations combined (Fig. 3). None of the tagged Gray Catbirds stopped at the same stopover site, and the closest sites were 24.7 $\mathrm{km}$ apart. Stopover sites for British Columbia Gray Catbirds were in Montana, Kansas, Oklahoma, Missouri, and Arkansas (Fig. 3). Stopover sites for Montana Gray Catbirds were in Kansas, Oklahoma, and Arkansas. The amount of time spent at each stopover site ranged between 1 to 16 days, but our estimate of stopover duration is limited by the sampling interval of the GPS tag ranging from 1 to 5 days during migration. From satellite imagery, stopover habitat generally included patches of trees or shrubby habitat, often within $500 \mathrm{~m}$ to water (satellite imagery of stopover sites can be found in additional file 2). The exception to the pattern of riparian habitat use was one stopover in an urban environment. The elevation of stopover sites varied widely, from 74 to $1060 \mathrm{~m}$ above sea level.

\section{Overwinter sites}

Gray Catbirds that bred in British Columbia and Montana had overlapping overwintering areas in Texas and Mexico. Gray Catbirds breeding in British Columbia overwintered in Texas, Tamaulipas, San Luis Potosi, Hidalgo, and Nuevo Leon, Mexico (Fig. 4 and Table 2). Gray Catbirds breeding in Montana overwintered in Texas, San Luis Potosi, Tamaulipas, Veracruz, Puebla, 
Table 1 Movement summary of Gray Catbirds (Dumetella carolinensis) fitted with GPS tags

\begin{tabular}{|c|c|c|c|c|c|c|c|c|c|c|c|c|c|c|c|}
\hline \multirow[b]{2}{*}{ Tag ID } & \multirow[b]{2}{*}{ Bird ID } & \multirow[b]{2}{*}{ Sex } & \multirow[b]{2}{*}{ Year } & \multirow[b]{2}{*}{ Fix } & \multirow[b]{2}{*}{ Loc. } & \multicolumn{5}{|l|}{ Fall } & \multicolumn{5}{|l|}{ Spring } \\
\hline & & & & & & Depart & Arrive & $\begin{array}{l}\text { Length } \\
\text { (Days) }\end{array}$ & $\begin{array}{l}\text { Distance } \\
(\mathbf{k m})\end{array}$ & $\begin{array}{l}\text { Speed } \\
(\mathbf{k m} / \\
\text { day) }\end{array}$ & Depart & Arrive & $\begin{array}{l}\text { Length } \\
\text { (Days) }\end{array}$ & $\begin{array}{l}\text { Distance } \\
(\mathbf{k m})\end{array}$ & $\begin{array}{l}\text { Speed } \\
\text { (km/day) }\end{array}$ \\
\hline \multicolumn{16}{|c|}{ British Columbia } \\
\hline 42000 & YRGX & M & 2017 & 23 & NLE & Sep 6 & $\begin{array}{l}\text { Oct } \\
12\end{array}$ & 36 & 3905 & 108 & - & - & - & - & - \\
\hline 42005 & YROX & M & 2017 & 53 & TX & Sep 10 & $\begin{array}{l}\text { Oct } \\
12\end{array}$ & 32 & 3236 & 101 & - & - & - & - & - \\
\hline 48964 & BBRX & M & 2018 & 46 & SLP & Sep 10 & $\begin{array}{l}\text { Oct } \\
16\end{array}$ & 36 & 4686 & 130 & - & - & - & - & - \\
\hline 48961 & BBXB & M & 2018 & 48 & TAM & Sep 12 & $\begin{array}{l}\text { Oct } \\
14\end{array}$ & 32 & 4098 & 128 & - & - & - & - & - \\
\hline 48965 & BBYX & M & 2018 & 51 & $\begin{array}{l}\text { TAM, SLP, } \\
\text { HID }\end{array}$ & Sep 16 & $\begin{array}{l}\text { Oct } \\
22\end{array}$ & 36 & 4171 & 116 & - & - & - & - & - \\
\hline 48963 & BBXD & $\mathrm{F}$ & 2018 & 28 & TAM $^{*}$ & Sep 6 & $\begin{array}{l}\text { Oct } \\
16\end{array}$ & 40 & 4192 & 105 & - & - & - & - & - \\
\hline Mean $\pm S$ & & & & & & & & $35 \pm 1.2$ & $\begin{array}{l}4048 \pm \\
193.5\end{array}$ & $\begin{array}{l}115 \pm \\
4.9\end{array}$ & & & & & \\
\hline \multicolumn{16}{|l|}{ Montana } \\
\hline 251 & LLBkA & $F$ & 2014 & 3 & TAM & - & Dec 7 & - & 3235 & - & - & - & - & - & - \\
\hline 262 & DBkAR & M & 2014 & 4 & $T X$ & - & Dec 7 & - & 2746 & - & - & - & - & - & - \\
\hline 245 & RAWW & M & 2014 & 2 & TAM & - & Jan 7 & - & 3507 & - & - & - & - & - & - \\
\hline 40958 & LRYA & M & 2016 & 8 & TAM, HID & - & $\begin{array}{l}\text { Oct } \\
18\end{array}$ & - & 3072 & - & - & - & - & - & - \\
\hline 48126 & LRYA & M & 2017 & 38 & $\begin{array}{l}\text { TAM, } \\
\text { HID }\end{array}$ & Sep 14 & $\begin{array}{l}\text { Oct } \\
19\end{array}$ & 35 & 3390 & 97 & Apr 26 & $\begin{array}{l}\text { May } \\
31\end{array}$ & 35 & 3501 & 100 \\
\hline 48120 & ODAS & M & 2017 & 41 & $\begin{array}{l}\text { TAM, VER, } \\
\text { HID }\end{array}$ & Sep 9 & $\begin{array}{l}\text { Oct } \\
14\end{array}$ & 33 & 3358 & 102 & May 3 & $\begin{array}{l}\text { May } \\
31\end{array}$ & 28 & 3424 & 122 \\
\hline 48121 & OOAS & $F$ & 2017 & 22 & VER & Sep 4 & $\begin{array}{l}\text { Oct } \\
29\end{array}$ & 55 & 3911 & 71 & - & - & - & - & - \\
\hline 48123 & DOGA & $\mathrm{F}$ & 2017 & 36 & TAM, HID & Sep 9 & $\begin{array}{l}\text { Oct } \\
14\end{array}$ & 35 & 3579 & 102 & Apr 26 & $\begin{array}{l}\text { May } \\
24\end{array}$ & 28 & 3764 & 134 \\
\hline 48124 & GOAS & F & 2017 & 40 & TAM, VER & Sep 19 & $\begin{array}{l}\text { Oct } \\
19\end{array}$ & 30 & 3407 & 114 & May 3 & $\begin{array}{l}\text { May } \\
31\end{array}$ & 28 & 3677 & 131 \\
\hline 48131 & WWAS & M & 2017 & 36 & $\begin{array}{l}\text { TAM, SLP, } \\
\text { VER }\end{array}$ & Sep 9 & $\begin{array}{l}\text { Oct } \\
14\end{array}$ & 35 & 4032 & 115 & - & - & - & - & - \\
\hline 48133 & RLGA & $\mathrm{F}$ & 2017 & 37 & TAM, PUE & Sep 9 & $\begin{array}{l}\text { Oct } \\
14\end{array}$ & 35 & 3401 & 97 & May 3 & - & - & - & - \\
\hline 48134 & ADBkW & M & 2017 & 37 & VER, HID & Sep 9 & Oct 4 & 25 & 3760 & 150 & & & & & \\
\hline \multicolumn{2}{|c|}{ Mean $\pm S E^{* *}$} & & & & & & & $35 \pm 3.2$ & $\begin{array}{l}3604 \pm \\
76.2\end{array}$ & $\begin{array}{l}106 \pm \\
7.8\end{array}$ & & & $29 \pm 2$ & $3591 \pm 78$ & $122 \pm 7.7$ \\
\hline
\end{tabular}

*Last fix on October 16, assuming overwintering site but could potentially still be on migration

**Mean ( \pm Standard Error) but not including length or speed for units with less than 10 fixes

Summary of GPS tags attached to Gray Catbirds in the South Okanagan Valley, British Columbia, Canada, and in the Bitterroot River Valley, Montana, USA with an emphasis on migration. Year is year GPS tag deployed. The fall depart date represents the last fix at the breeding site and the arrival date represents the first fix at the overwintering site. The spring depart date represents the last fix at the overwintering site and the arrival date represents the first fix back at the breeding site. Locations (Loc.) are abbreviated as Nuevo Leon (NLE), San Luis Potosi (SLP), Tamaulipas (TAM), Veracruz (VER), Hidalgo (HID), Puebla (PUE), and Texas (TX). Dashes indicate missing data: fall depart date is unclear from three Bitterroot River Valley catbirds due to first fixes occurring mid-migration; lack of spring migration data is due to premature battery exhaustion

and Hidalgo. Gray Catbirds breeding in British Columbia traveled an average of $4048 \pm 193 \mathrm{~km}$ to overwintering locations, and Gray Catbirds breeding in Montana traveled $3604 \pm 76 \mathrm{~km}$ to overwintering locations.
Overwintering location estimates from birds with geolocators were less precise than GPS tags but also encompassed San Luis Potosi, Tamaulipas, and Veracruz (Fig. 5). One exception is a Gray Catbird with a 


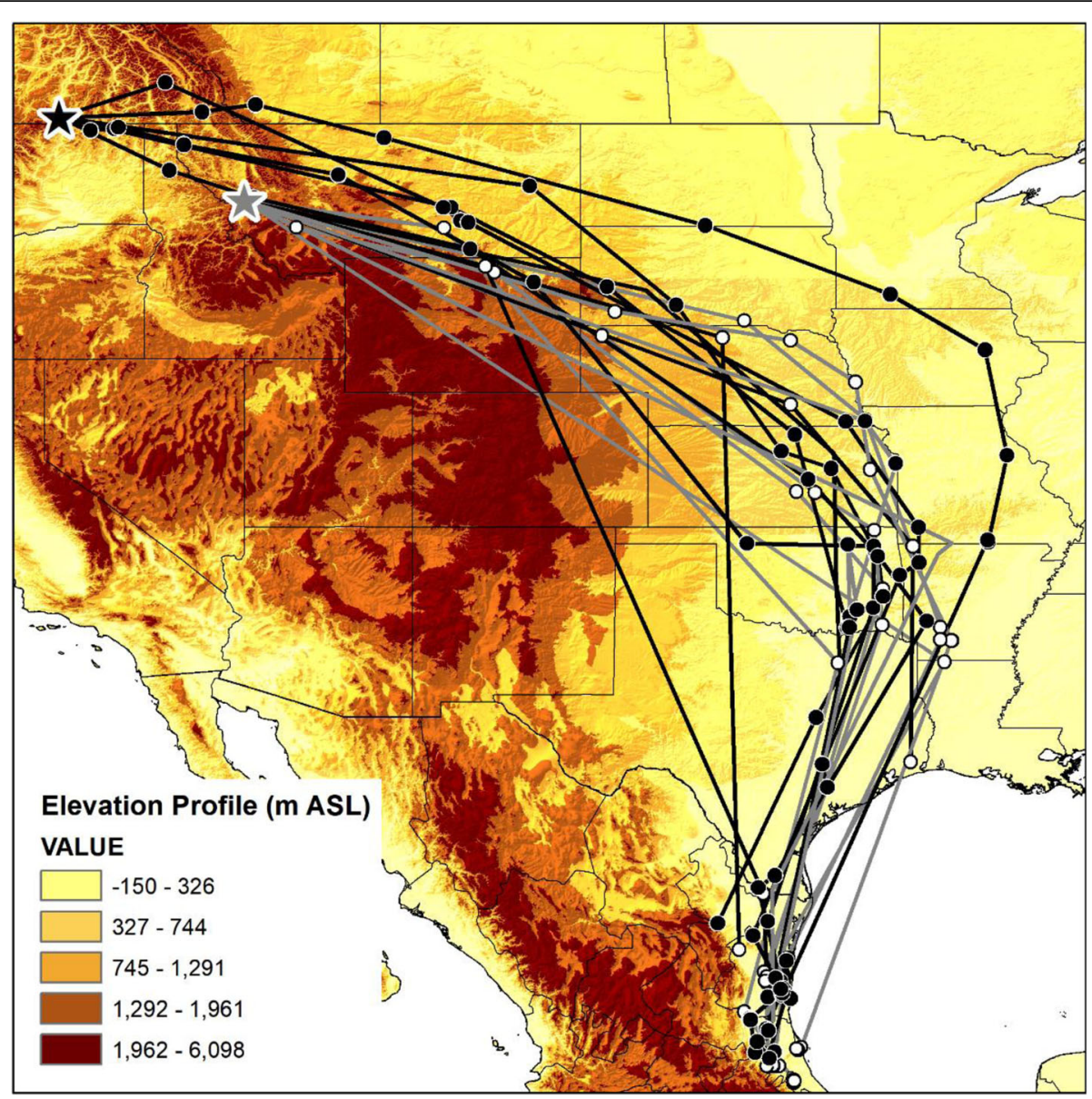

Fig. 1 Gray Catbird (Dumetella carolinensis) fall migration route. Southward migration path from GPS tags retrieved from Gray Catbirds breeding in the South Okanagan Valley, British Columbia, Canada, and in the Bitterroot River Valley, Montana, USA. Gray tracks are from GPS tags retrieved from catbirds in the Bitterroot River Valley $(n=12)$ and black tracks are from GPS tags retrieved from catbirds in the South Okanagan Valley $(n=6)$. World Terrain Base Map provided by ESRI, USGS, and NOAA within ArcMap 10.7.1. Map created in ArcMap 10.7.1 (ESRI 2019) using the GCS WGS 1984 coordinate system. The elevation map was created in ArcMap 10.7.1 using the 30 arc-second digital elevation model of North America (ESRI 2019)

geolocator whose overwintering estimate was centered over Oaxaca, Mexico, and the Pacific Ocean - the longitude of this estimate is in accordance with all other Gray Catbird overwintering estimates but the latitude appears suspect (Fig. 5).
From GPS tags, we found that several Gray Catbirds from Montana and British Columbia populations used more than one overwintering location, with up to four distinct locations documented (Table 2). Each subsequent overwintering location was farther south than the

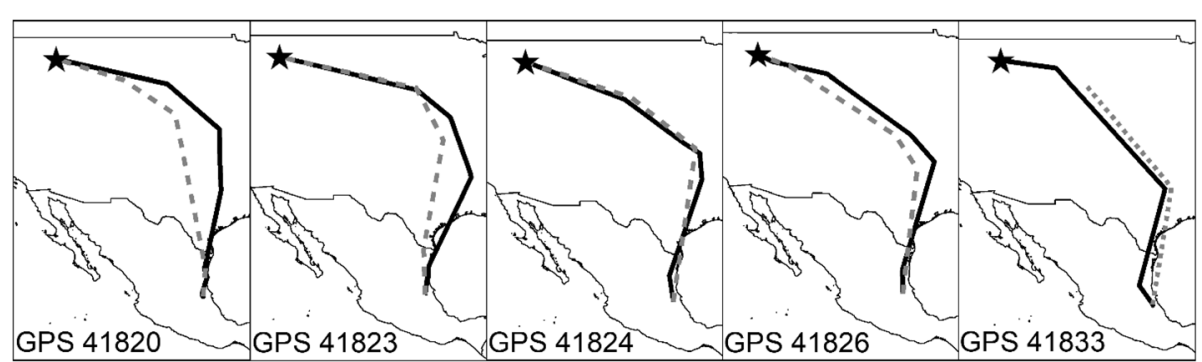

Fig. 2 Comparing north vs. south migration routes for Gray Catbirds (Dumetella carolinensis). A comparison of southward (black) and northward migration (gray) GPS tracks from 5 different Gray Catbirds marked in their breeding site in the Bitterroot River Valley, Montana, USA. All birds were heading north by May 10, except for catbird with GPS 41820, who headed north by May 3. Map created in ArcMap 10.7.1 using the GCS WGS 1984 coordinate system (ESRI 2019) 


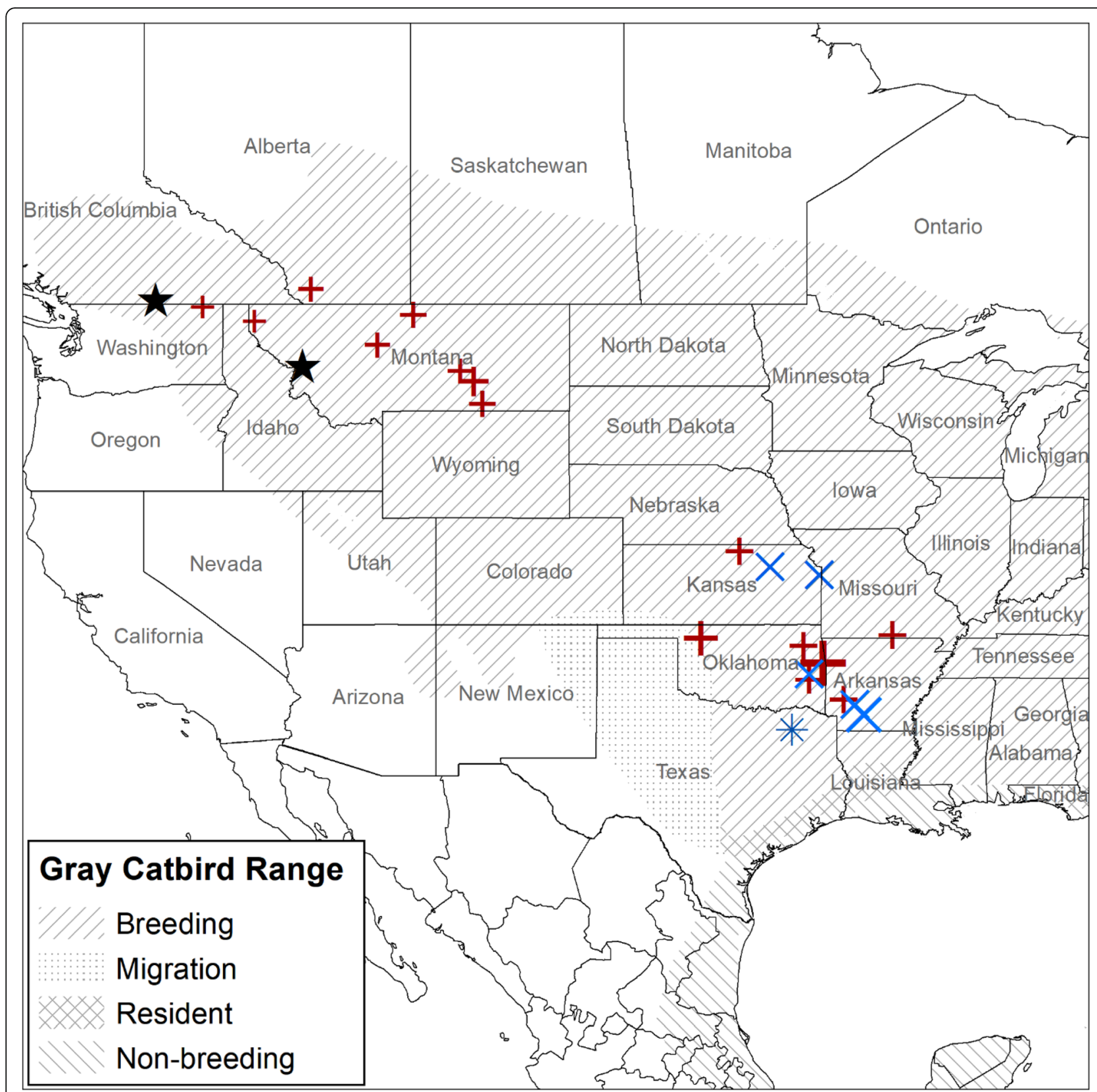

Fig. 3 Migration stopover sites identified for Gray Catbirds (Dumetella carolinensis). Stopover sites identified using GPS tags. Crosses represent birds tagged in the South Okanagan Valley, British Columbia, Canada, and exes represent birds tagged in the Bitterroot River Valley, Montana, USA. Stars represent study site locations. All sites are from fall migration, except for the asterisk in Texas, which was a spring stopover site for a Gray Catbird that bred in the Bitterroot River Valley. Points are scaled relative to the amount of time spent at a site and range between 1 and 16 days. Gray Catbird range map provided by IUCN (2016). Map created in ArcMap 10.7.1 using the GCS WGS 1984 coordinate system (ESRI 2019)

previous one, except one Gray Catbird who moved slightly farther north for his second overwintering location, then south for subsequent locations. Distance between overwintering locations ranged from 5 to $353 \mathrm{~km}$. The length of stay at any one overwintering location ranged from 17 to 169 days. During winter, Gray Catbirds occupied natural areas with dense vegetative cover, often in association with edges or riparian habitats, at elevations of 9-678 m above sea level (satellite imagery of overwintering locations can be found in additional file 2).

\section{Multiple years of tracking}

Some birds tracked over multiple years in Montana showed fidelity to overwintering locations (Fig. 6). One female Gray Catbird had two similar overwintering locations based on one GPS tag and one geolocator. This individual also had 


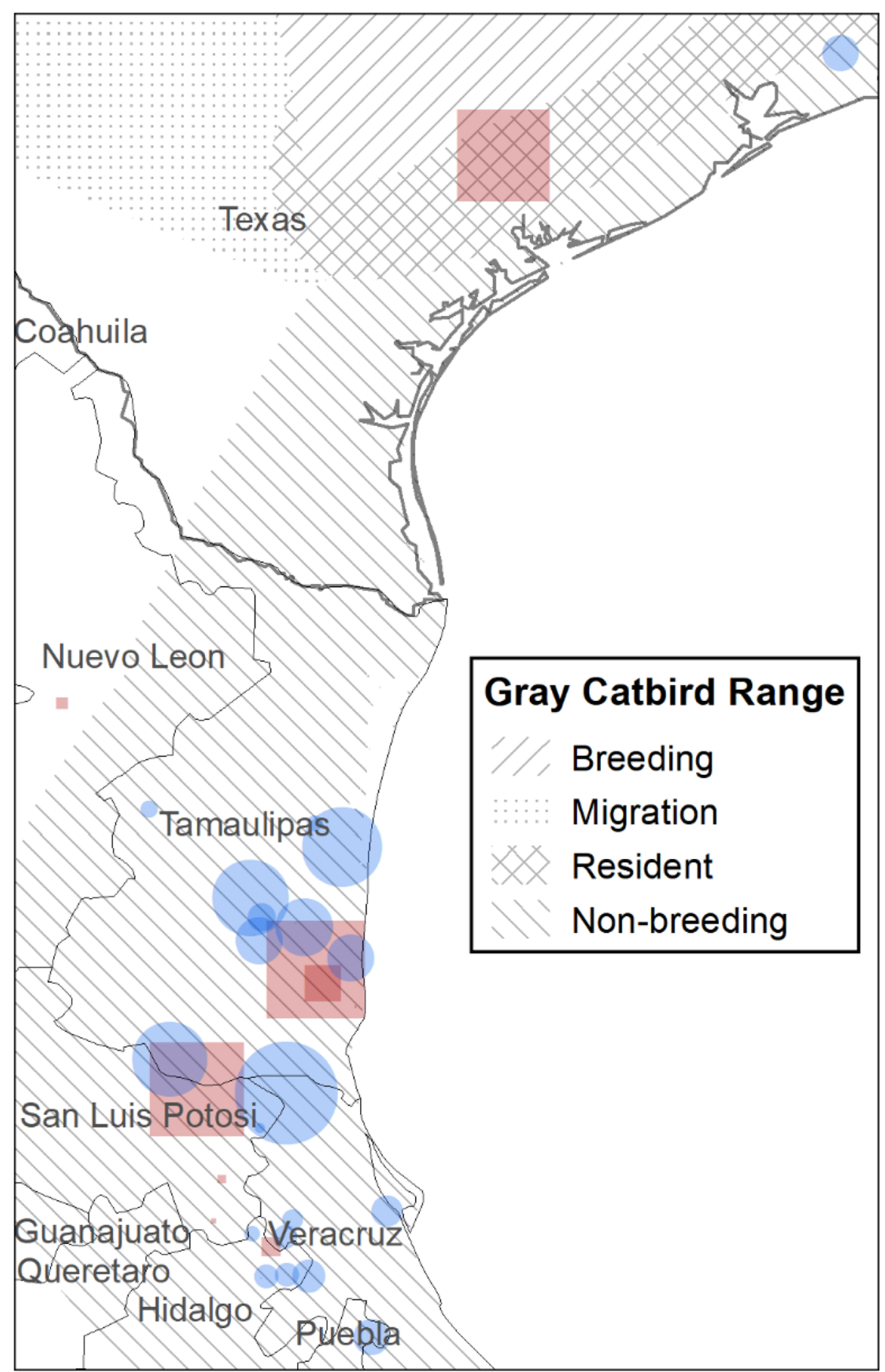

Fig. 4 Gray Catbird (Dumetella carolinensis) overwintering sites. Overwintering points were determined from GPS tags retrieved from Gray Catbirds breeding in the South Okanagan Valley, British Columbia, Canada (red squares), and the Bitterroot River Valley, Montana, USA (blue circles). The size of the symbol represents how long the bird stayed at the site, ranging from 4 to 169 days. Most birds had more than one overwintering site. Gray Catbird range map provided by IUCN (2016). Map created in ArcMap 10.7.1 (ESRI 2019) using the GCS WGS 1984 coordinate system

the potentially unreliable geolocator where latitude estimates appeared unlikely. One male Gray Catbird had likely different overwintering estimates, with one geolocator showing
Mexico and one GPS tag showing Texas. Another male Gray Catbird showed strong overwintering fidelity over two years based on data from two GPS tags. 
Table 2 Summary of Gray Catbird (Dumetella carolinensis) overwintering locations identified using GPS tags

\begin{tabular}{|c|c|c|c|c|c|c|c|c|c|c|c|c|c|c|c|}
\hline \multirow[b]{2}{*}{ Tag ID } & \multicolumn{3}{|c|}{ Winter Location 1} & \multicolumn{4}{|c|}{ Winter Location 2} & \multicolumn{4}{|c|}{ Winter Location 3} & \multicolumn{4}{|c|}{ Winter Location 4} \\
\hline & Dates & State & Days & Dates & State & Days & $\mathrm{KM}$ & Dates & State & Days & KM & Dates & State & Days & KM \\
\hline \multicolumn{16}{|c|}{ British Columbia } \\
\hline 42000 & Oct 12-Nov 1 & NLE & 20 & & & & & & & & & & & & \\
\hline 42005 & Oct 12-Mar 9 & TX & 158 & & & & & & & & & & & & \\
\hline 48964 & Oct 16-Mar 27 & SLP & 162 & Mar 31-Apr 10 & SLP & 10 & 109 & & & & & & & & \\
\hline 48961 & Oct 14-Apr 2 & TAM & 169 & & & & & & & & & & & & \\
\hline 48965 & Oct 22-Oct 26 & TAM & 4 & Dec 1-Feb 1 & TAM & 62 & 32 & Mar 1-Mar 17 & SLP & 16 & 178 & Mar 19-Apr 20 & HID & 32 & 67 \\
\hline 48963 & Oct 16 & TAM & & & & & & & & & & & & & \\
\hline \multicolumn{16}{|c|}{ Bitterroot River Valley } \\
\hline 251 & Dec 7-Jan 7 & TAM & 30 & & & & & & & & & & & & \\
\hline 262 & Dec 7-Feb 7 & TX & 62 & & & & & & & & & & & & \\
\hline 245 & Jan 7 & TAM & & & & & & & & & & & & & \\
\hline 40958 & Oct 18-Jan 5 & TAM & 79 & Feb 4 & TAM & & 19 & Mar 1 & HID & & 278 & & & & \\
\hline $48126+$ & Nov 1-Nov 21 & TAM & 20 & Dec 1-Feb 19 & TAM & 80 & 5 & Mar 15-Apr 26 & HID & 42 & 275 & & & & \\
\hline 48120 & Oct 14-Nov 11 & TAM & 28 & Dec 1-Feb 19 & TAM & 81 & 114 & Mar 8-Apr 19 & VER & 41 & 234 & Apr 26-May 3 & VER & 7 & 8 \\
\hline 48121 & Oct 29-Dec 21 & VER & 53 & Dec 31 & VER & & 6 & & & & & & & & \\
\hline 48123 & Oct 14-Mar 1 & TAM & 138 & Mar 15-Apr 26 & HID & 42 & 353 & & & & & & & & \\
\hline 48124 & Oct 19-Mar 1 & TAM & 133 & Mar 8-May 3 & VER & 56 & 313 & & & & & & & & \\
\hline 48131 & Oct 14-Jan 20 & TAM & 98 & Feb 19-Mar 8 & SLP & 17 & 168 & Mar 22-Apr 26 & VER & 35 & 79 & & & & \\
\hline 48133 & Oct 14-Feb 19 & TAM & 128 & Mar 29-May 3 & PUE & 63 & 275 & & & & & & & & \\
\hline 48134 & Oct 14-Mar 29 & VER & 176 & Apr 5-May 3 & HID & 28 & 119 & & & & & & & & \\
\hline
\end{tabular}

+This bird moved around in Tamaulipas between Oct 19 and Nov 1

Details of overwintering sites obtained from GPS tags placed on Gray Catbirds in the South Okanagan Valley, British Columbia, Canada, and the Bitterroot River Valley, Montana, USA. Abbreviations include minimum length of stay (Days), the distance between current and previous overwintering site (KM). States are abbreviated as Nuevo Leon (NLE), San Luis Potosi (SLP), Tamaulipas (TAM), Veracruz (VER), Hidalgo (HID), Puebla (PUE), and Texas (TX)

\section{Migratory connectivity}

We observed weak migratory connectivity for British Columbia and Montana catbird populations; there was no significant correlation between the distances of birds in the breeding grounds and the distances of birds in the overwintering grounds $\left(\mathrm{r}_{\mathrm{M}}=0.013, P\right.$-value $\left.=0.41\right)$. Additionally, the average pairwise distances in the overwintering grounds (British Columbia: $347.2 \pm 68.3 \mathrm{~km}, n=$ 15, Montana: $255.8 \pm 34.7 \mathrm{~km}, n=66$ ) were greater than the average pairwise distances in the breeding grounds (British Columbia: $0.74 \pm 0.11 \mathrm{~km}, \mathrm{n}=15$, Montana: $0.02 \pm 0.002 \mathrm{~km}, \mathrm{n}=66$ ), highlighting the degree of spread between different phases of the annual cycle.

\section{Apparent annual survivorship}

The top model for apparent annual survivorship of Montana Gray Catbirds included sex and site and had a weight of $93 \%$ and no other model had an $\Delta \mathrm{AIC}_{\mathrm{c}}$ value of $<2$, suggesting that this model had the greatest support (Table 3). Therefore, parameter estimates for this model alone are reported. The apparent annual survivorship was greater for males $(\phi=0.43 \pm 0.04)$ than females $(\phi=0.34 \pm 0.05$, Table 4$)$.
The top model for apparent annual survivorship of British Columba Gray Catbirds included sex and had a weight of $98 \%$ and no other model had an $\Delta \mathrm{AIC}_{\mathrm{c}}$ value of $<2$. Therefore, parameter estimates for this model alone are reported. The top model for apparent annual survivorship in British Columbia included sex as a covariate for both survivorship and detection probability (Table 1). Males had greater detection probability $(p=0.72 \pm 0.07)$ than females $(p=0.25 \pm 0.07)$ and birds of unknown sex $(p=$ 0.35 ) but males and females had similar survivorship ( $\phi=$ $0.64 \pm 0.05$ and $0.61 \pm 0.06$, respectively, Table 4).

\section{Discussion}

This study represents the first published information on migration, overwintering locations, and survival rates of western populations of Gray Catbirds. As such, it contributes to our collective knowledge of the species and provides baseline information against which to monitor future population change.

Our findings support past suspicions that western catbirds follow the Central Flyway, despite breeding locations within the Pacific Flyway. The Rocky Mountains did not appear to be a barrier during fall and spring 


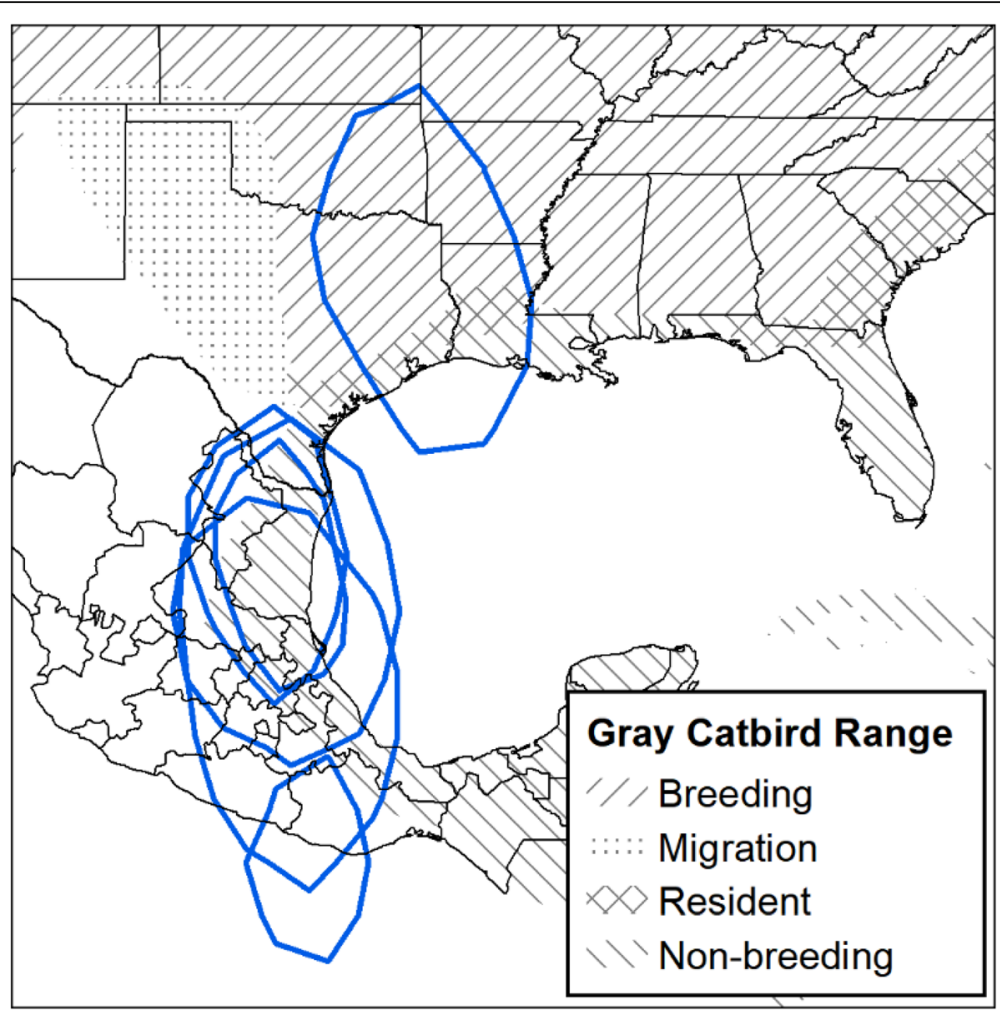

Fig. 5 Overwintering locations of Gray Catbirds (Dumetella carolinensis) breeding in the Bitterroot River Valley, Montana, USA. Each polygon represents the 50\% Kernel Density Estimates from locations obtained from archival light-level geolocators between November 15 - March 1 for 1 year from 2014 to 2018. Gray Catbird range map provided by IUCN (2016). Map created in ArcMap 10.7.1 (ESRI 2019) using the GCS WGS 1984 coordinate system

migration. GPS data from British Columbia catbirds further highlight that low-elevation corridors are likely used to cross the mountainous landscape.

The migration route for western Gray Catbirds may reflect the evolution of migration in these populations during historical range expansion, similar to Veeries in British Columbia [22]. As is postulated for Veeries, Gray
Catbirds likely originated in eastern North America and then slowly expanded their range northward and then westward as the continental glaciers receded [22]. The absence of this species in most of the Pacific Northwest, such as coastal Washington, Oregon, and California, is consistent with this hypothesis. The relicts of historical range expansions are recapitulated in migration and can

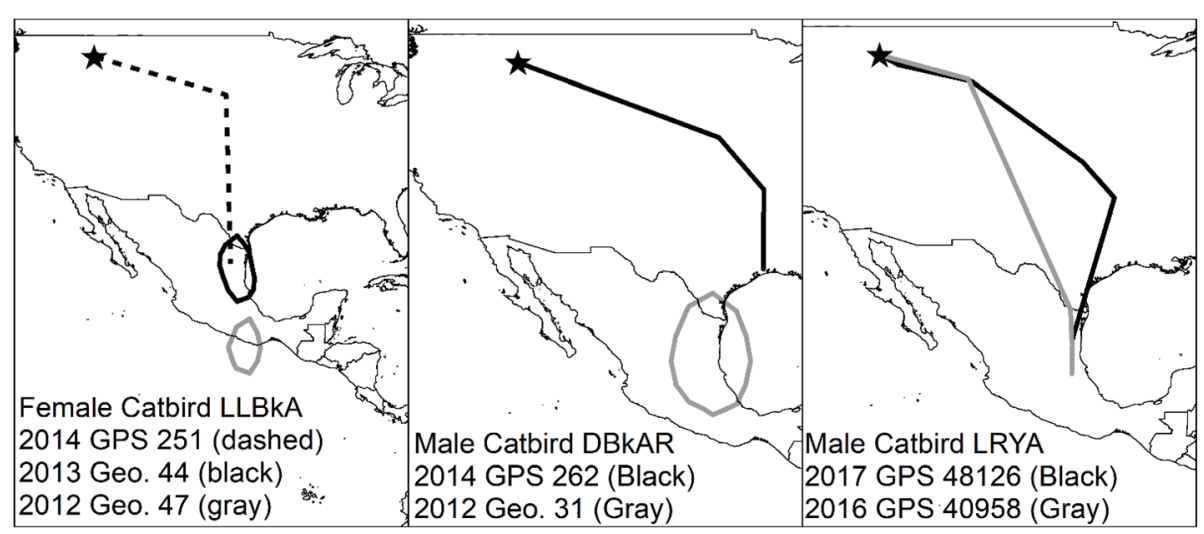

Fig. 6 Repeat tracking of 3 separate Gray Catbirds (Dumetella carolinensis) in different years. Tracking devices were deployed in the Bitterroot River Valley, Montana, USA. The year that the track was recorded is shown. Map created in ArcMap 10.7.1 (ESRI 2019) using the GCS WGS 1984 coordinate system. Geolocator abbreviated as Geo 
Table 3 Gray Catbird (Dumetella carolinesis) apparent annual survivorship model comparison

\begin{tabular}{|c|c|c|c|c|c|}
\hline Model & Parameters & $\mathrm{AIC}_{\mathrm{c}}$ & $\Delta \mathrm{AIC}$ & Weight & Deviance \\
\hline \multicolumn{6}{|l|}{ Montana $(n=741)$} \\
\hline$\varphi($ sex) $p$ (site) & 5 & 496.4 & 0.00 & 0.93 & 159.9 \\
\hline$\varphi($ sex $) p()$. & 4 & 503.0 & 6.56 & 0.04 & 130.5 \\
\hline$\varphi$ (site) $p$ (sex) & 5 & 503.7 & 7.27 & 0.02 & 167.2 \\
\hline$\varphi($ sex $) p($ sex $)$ & 6 & 506.8 & 10.36 & 0.01 & 130.2 \\
\hline$\varphi() p.(\operatorname{sex})$ & 4 & 511.3 & 14.91 & 0.00 & 138.9 \\
\hline$\varphi($ TSM) p (sex) & 5 & 513.3 & 16.94 & 0.00 & 138.9 \\
\hline$\varphi($ TSM) p (.) & 3 & 552.4 & 56.00 & 0.00 & 65.2 \\
\hline$\varphi($ site) $p()$. & 3 & 596.4 & 100.00 & 0.00 & 124.3 \\
\hline$\varphi(.) \mathrm{p}$ (site) & 3 & 596.5 & 100.14 & 0.00 & 124.4 \\
\hline$\varphi$ (site) p (site) & 4 & 598.2 & 101.76 & 0.00 & 124.0 \\
\hline$\varphi$ (TSM) p (site) & 4 & 598.6 & 102.17 & 0.00 & 124.4 \\
\hline$\varphi() p.()$. & 2 & 600.7 & 104.20 & 0.00 & 115.4 \\
\hline \multicolumn{6}{|c|}{ British Columbia $(n=537)$} \\
\hline$\varphi($ sex $) p($ sex $)$ & 6 & 709.2 & 0.00 & 0.98 & 119.2 \\
\hline$\varphi($ sex $) p()$. & 4 & 718.1 & 8.91 & 0.01 & 132.1 \\
\hline$\varphi($ sex $) p($ site) & 5 & 719.4 & 10.16 & 0.01 & 164.3 \\
\hline$\varphi$ (site) $p$ (sex) & 5 & 724.0 & 14.82 & 0.00 & 169.0 \\
\hline$\varphi() p.($ sex $)$ & 4 & 724.2 & 15.00 & 0.00 & 138.2 \\
\hline$\varphi(\mathrm{TSM}) \mathrm{p}(\mathrm{sex})$ & 5 & 726.1 & 16.91 & 0.00 & 138.1 \\
\hline$\varphi($ TSM) $p()$. & 3 & 813.4 & 104.24 & 0.00 & 51.1 \\
\hline$\varphi($ TSM) p (site) & 4 & 815.4 & 106.22 & 0.00 & 76.4 \\
\hline$\varphi() p.()$. & 2 & 836.7 & 127.48 & 0.00 & 76.4 \\
\hline$\varphi($ site) $p()$. & 3 & 838.5 & 129.34 & 0.00 & 101.6 \\
\hline$\varphi(.) \mathrm{p}$ (site) & 3 & 838.6 & 129.45 & 0.00 & 101.7 \\
\hline$\varphi$ (site) p (site) & 4 & 839.7 & 130.48 & 0.00 & 100.7 \\
\hline
\end{tabular}

Models for the apparent annual survivorship of Gray Catbirds in the South Okanagan Valley, British Columbia, Canada, and the Bitterroot River Valley, Montana, USA. Cormack-Jolly-Seber models were used, which include annual survivorship $(\phi)$ and detection probability (p). TSM is a time-since-marking approach whereby the first encounter is separated from separate encounters to factor in young and transient individuals. Intercept only models are designated by (.)

be observed in other species whose breeding and overwintering grounds are continents apart, such as Northern Wheatear (Oenanthe oenanthe [56]), Bar-tailed Godwit (Limosa lapponica [57]), and Blackpoll Warbler (Setophaga striata [58]). In British Columbia, ancestral routes similar to what we have found in the western Gray Catbird have also been observed in Swainson's Thrushes [20,59], but our study is the first to document this phenomenon in the Mimidae family.

Ancestral relicts of range expansion may also work in conjunction with ecological limitations to explain why the migratory routes we documented are indirect and farther east than we expected [60]. Gray Catbirds occupy riparian habitat and shrubby edges throughout their range [40, 61]. Riparian habitats identified at our stopover locations suggest these cover types may be of particular importance during migration by providing both food and water, as has been documented for other bird species [4, 62, 63]. Indeed, fall stopover sites appear concentrated after migrating along the edge of the semiarid great plains and reaching the temperate forest ecoregion, replete with wetlands, forests, and a temperate climate [64]. Therefore, catbirds taking the easterly route may have experienced an evolutionary advantage by spending more time in higher quality stopover habitat even as their range expanded westward.

In addition to confirming that catbirds use riparian and edge habitats for stopovers, we also found stopover locations dispersed on the landscape and not used repeatedly or by the same birds, though we acknowledge we have a relatively small sample size and this topic merits further study. Dispersed and abundant stopover sites pose a challenge for conservation as the persistence of many small riparian areas along the migration route may be necessary to support current Gray Catbird populations. Alternatively, perhaps the loss of any one patch of habitat is less consequential as long as a certain threshold of suitable habitat is maintained at the landscape scale. We suggest additional study into important features of stopover locations and to what extent catbirds are plastic in their use of such sites. Conserving a network of riparian habitats across the landscape is a valuable conservation approach for not just Gray Catbirds, but other wildlife, as it allows for landscape-level connectivity and the retention of movement corridors.

Birds from both of our study populations overwintered along the Gulf Coast of Texas south into northeastern Mexico, with the highest concentration in the Tamaulipas region. These sites do not overlap with known overwintering locations of Midwestern and mid-Atlantic catbirds [13] and thus represent a major advance in our understanding of the precise geographic linkages between breeding and overwintering catbird populations. We also saw some evidence of overwintering site fidelity, though potentially erroneous geolocator data limits our ability to confirm this behaviour across many individuals. In any case, repeated tracking of individual songbirds over multiple years is rare and, even if limited by sample size and technology, represents a major accomplishment of our study.

Our study is the first to document Gray Catbird's use of multiple overwintering locations; we found individuals used multiple overwintering locations and moved farther south as the winter progressed into spring. The use of more than one overwintering location has been observed in a few other neotropical migrants (e.g. Prothonotary Warblers (Protonotaria citrea), Veeries, and Swainson's Thrushes [22, 65-67]). Future tracking studies on 
Table 4 Gray Catbird (Dumetella carolinensis) apparent annual survivorship model parameter estimates

\begin{tabular}{|c|c|c|c|c|}
\hline Model & Parameter & Group & Estimate & Standard Error \\
\hline \multicolumn{5}{|l|}{ Montana } \\
\hline$\varphi($ sex $) p($ site) & $\varphi$ & Female & 0.34 & 0.05 \\
\hline$\varphi($ sex $) p($ site) & $\varphi$ & Male & 0.43 & 0.04 \\
\hline$\varphi($ sex $) p($ site $)$ & $\varphi$ & Unknown & 0.06 & 0.01 \\
\hline$\varphi($ sex $) p($ site $)$ & $p$ & MPG Ranch & 0.77 & 0.07 \\
\hline$\varphi$ (sex) p (site) & $p$ & Other & 0.34 & 0.10 \\
\hline \multicolumn{5}{|l|}{ British Columbia } \\
\hline$\varphi($ sex $) p($ sex $)$ & $\varphi$ & Female & 0.61 & 0.06 \\
\hline$\varphi(\operatorname{sex}) p($ sex $)$ & $\varphi$ & Male & 0.64 & 0.05 \\
\hline$\varphi($ sex $) p($ sex $)$ & $\varphi$ & Unknown & 0.20 & 0.20 \\
\hline$\varphi($ sex $) p($ sex $)$ & $p$ & Female & 0.25 & 0.07 \\
\hline$\varphi($ sex $) p($ sex $)$ & $p$ & Male & 0.72 & 0.07 \\
\hline$\varphi(\operatorname{sex}) p(\operatorname{sex})$ & $\mathrm{p}$ & Unknown & 0.35 & 0.13 \\
\hline
\end{tabular}

Parameter estimates for the top apparent annual survivorship models for Gray Catbirds in British Columbia and Montana. Cormack-Jolly-Seber models were used, which include annual survivorship $(\phi)$ and detection probability $(p)$

additional species would help us understand if this behaviour is rare or common amongst neotropical migrants. The mechanisms driving overwinter movement warrants further research; plausible explanations may be that birds follow a shift in seasonal food resources or avoid weather events. A better understanding of overwintering habitat use and how it may vary by age and sex is a priority for future Gray Catbird research [40]. The ability of individuals to exhibit some plasticity in overwintering locations, suggests a life-history strategy adapted to landscape change. From a conservation perspective, the potential plasticity of overwintering site use may be an adaptive strategy that will bode well for the future of catbird populations to persist as habitats shift due to anthropogenic or natural causes.

That Gray Catbirds use multiple overwintering locations and vary in their degree of overwintering location fidelity question important assumptions of overwintering monitoring programs, such as Monitoreo de Sobreviviencia Invernal (MoSI), which uses standardized mistnetting efforts during the overwintering period to assess overwintering survivorship [68]. The MoSI protocol involves 5 monthly overwinter mist-netting pulses from November to the end of March where each pulse occurs over 2-3 days [69]. The Gray Catbird was one target species for the MoSI program but their overwintering survivorship estimates will likely be underestimated given their overwinter movements [69]. A better understanding of songbird overwintering movement and site fidelity in other species is crucial to assessing the accuracy of vital rate metrics derived from MoSI data.

\section{Migratory connectivity}

We found weak migratory connectivity for the two Gray Catbird populations we examined, with Montana and
British Columbia Gray Catbirds overwintering in similar areas across northeastern Mexico. Birds that bred close to one another dispersed up to $1000 \mathrm{~km}$ apart during the overwintering period. Weak migratory connectivity may be advantageous for the persistence of western catbird populations because individuals are dispersed across a large geographic region during the overwintering period are unlikely to be affected by local threats.

One challenge in comparing migratory connectivity between studies is the scale in which it is examined. If we consider both breeding sites from British Columbia and Montana as one population, and the span of Texas to Veracruz as one overwintering population, it would be perceived as strong migratory connectivity. Ryder et al. [13] reported strong migratory connectivity for eastern and central populations of Gray Catbirds. Regardless, the results of our study and previous studies on migration patterns of Gray Catbirds result in a comprehensive picture of population connectivity across their range. Gray Catbirds breeding in the west overwinter in Texas and northeastern Mexico [this study and 94]. Catbirds breeding in the mid-west overwinter in Central America [13], Catbirds breeding near the Great Lakes overwinter in Guatemala [70] and Catbirds breeding in the Atlantic overwinter in Cuba and the Caribbean Islands [13].

\section{Apparent annual survivorship}

Establishing demographic rates for species, such as apparent annual survivorship, are important for identifying populations at risk of decline and informing conservation efforts [11, 71]. The estimates for Gray Catbirds in British Columbia ( $0.61 \pm 0.06$ female, $0.64 \pm 0.05$ males) exceed reported adult average survivorship values in the 
Northern Rockies bird conservation region (which spans both study areas) of $0.54 \pm 0.02$ between 1992 and 2006 [72]. For comparison, apparent annual adult survivorship for other common songbirds in the Northern Rockies bird conservation region ranges between 0.50-0.59 [72]. Why the apparent annual survivorship estimates for Montana Gray Catbirds $(0.34 \pm 0.05$ females, $0.41 \pm 0.04$ males) are lower is unclear. However, when averaged across both sites, survivorship values match those of the general Northern Rockies conservation region, so perhaps the range of values we are documenting at local sites are in line with regional trends. Because birds from both study areas traveled along similar routes and overwintered in similar locations, differences are likely attributed to breeding locations. Breeding site fidelity in catbirds is linked with reproductive success, where birds that successfully reproduce are more likely to return to the same territory, therefore probing deeper into nest success in Montana might provide more insight into apparent annual survivorship trends [73]. Additionally, the degree of urbanization between the two sites may be relevant, as eastern catbirds exhibit lower survival in rural than urban areas (suspected due to food availability), and our Montana site was more rural than our British Columbia site [74]. Both study areas had resighting efforts, which when combined with recapture methods, improves apparent annual survivorship estimates [75]. However, overall resighting effort in Montana was slightly lower than in British Columbia, and therefore, could have skewed the results. As technology advances, we are hopeful that one day we will be better able to understand whether birds that do not return to the site in subsequent years are dispersing to new areas, remain undetected, or are dying.

\section{Conclusions}

Our study represents the first description of full annual cycle movements of western populations of Gray Catbirds, revealing that catbirds breeding in two disparate populations followed similar migratory routes eastward across the Rocky Mountain Range then southward towards overwintering locations in northeastern Mexico and Texas, following a putative ancestral route. During the non-breeding season, individuals from both breeding populations spread out across overlapping geographic areas, a case of weak migratory connectivity. Unexpectedly, Gray Catbirds used multiple overwintering locations which suggests some plasticity in movement that may help catbirds remain adaptable if landscapes change. Like many previous catbird studies, our research found that western catbird populations use riparian and shrubby plant communities for breeding, stopover sites, and overwintering sites.
From a conservation perspective, the detail we now have on the full annual cycle of Gray Catbirds may help in ensuring the species remains a common species on the landscape well into the future. Preserving key areas of suitable habitat in the central and southern portions of Tamaulipas would benefit both Montana and British Columbia Gray Catbirds because our study identified Tamaulipas as a key overwintering area. Additionally, with the predicted effects of climate change impacting the persistance and quality of riparian habitats, proactively protecting and monitoring riparian areas along their migration route and stopover areas may allow us to detect changes early [76, 77]. Moreover, should a population decline occur in the future, the baseline information on the survivorship and migratory connectivity of these populations we describe in detail will be valuable for conservation efforts [78].

\section{Abbreviations \\ AIC: Akaike's Information Criteria; GPS: Global Positioning System; MoSI: Monitoreo de Sobreviviencia Invernal; $r_{M}$ : Mantel's correlation; USA: United States of America}

\section{Supplementary Information}

The online version contains supplementary material available at https://doi. org/10.1186/s40462-021-00249-7.

Additional file 1. Low-quality geolocator results. Additional file 1 shows an example of low-quality archival light-level geolocator data and the associated geographic assignment locations.

Additional file $\mathbf{2}$ Aerial imagery of stopover and overwintering sites. Shows satellite imagery of stopover and overwintering site locations as determined from GPS tags attached to Gray Catbirds (Dumetella carolinensis).

\section{Acknowledgements}

We thank all the skilled field technicians and volunteers who deployed and retrieved tracking devices as well as resighting and recapturing colourbanded catbirds, including T. Forrester, A. Huang, K. Owen, M. Bieber, M. Aubertin-Young, S. Hudson, K. Hick, A.M. Bezener, H. Hall, A. Gonzalez, S. English, S. Fuller, M. Ruggles, A. Spidal, C. Taft, L. Fried, and A. Meyer. T. Rodriguez helped prepare data files for M. Blake who modelled the coding in RMark for analysis of the survivorship of Montana Catbirds. M. Blake and L. Fried also substantially increased our sample size during the 2018 field effort. We thank the En'owkin Centre and the Penticton Indian Band for their collaborative efforts with this research. J. Pither, J. Alexander, and A. Ford suggested improvements to a draft of this manuscript. We thank K. Hobson and S. Van Wilgenburg for initiating the study of Gray Catbirds in British Columbia and for technical help with fitting geolocators.

\section{Authors' contributions}

$\mathrm{CAB}, \mathrm{MAF}, \mathrm{KEH}$, and KRS conceived the project idea and contributed substantial materials, resources, and funding. Field data were collected by MAF, KAM, and MBL. KAM performed data analyses, created all figures and tables, and wrote the manuscript with guidance from $K E H, C A B, M A F$, and KRS. All authors read and approved the final manuscript.

\section{Funding}

Funding was provided by Environment and Climate Change Canada, the University of British Columbia Okanagan, Natural Sciences and Engineering Research Council of Canada for the study design, data collection in Canada, analysis, interpretation, and writing of the manuscript. Funding was provided by Montana State University, and MPG Ranch for the study design, data 
collection in the USA, survivorship analysis for catbirds in the USA, and editorial advice.

\section{Availability of data and materials}

The datasets supporting the conclusions of this article will be available in the Open Science Framework repository.

\section{Ethics approval and consent to participate}

All research on birds was approved by the University of British Columbia Okanagan Animal Care Committee (application number A16-0079) and the University of Montana Institutional Animal Care and Use Committee (02217). Federal bird banding permits (10761 L,10761Q, 10761R, 23206) and Montana Fish, Wildlife, and Parks permits were acquired for bird banding activities in Montana.

\section{Consent for publication}

Not applicable.

\section{Competing interests}

The authors declare that they have no competing interests.

\section{Author details}

${ }^{1}$ Department of Biology, University of British Columbia Okanagan, Kelowna, British Columbia, Canada. ${ }^{2}$ Division of Biological Sciences, University of Montana, Missoula, MT, USA. ${ }^{3}$ Science and Technology Branch, Environment and Climate Change Canada, Delta, British Columbia, Canada. ${ }^{4}$ Oliver, Canada. ${ }^{5}$ MPG Ranch, Florence, MT, USA.

\section{Received: 16 November 2020 Accepted: 24 February 2021}

\section{Published online: 17 March 2021}

\section{References}

1. Rosenberg KV, Dokter AM, Blancher PJ, Sauer JR, Smith AC, Smith PA, et al Decline of the North American avifauna. Science (80- ). 2019:366:120-4.

2. Sauer JR, Pardieck KL, Ziolkowski DJ, Smith AC, Hudson MR, Rodriguez V, et al. The first 50 years of the north American breeding bird survey. Condor. 2017;119:576-93.

3. Lovejoy TE. Foreward. In: Elphick J, editor. Atlas Bird Migr. Richmond Hill, Ontario: FireFly Books Ltd.; 2007. p. 4.

4. Carlisle JD, Skagen SK, Kus BE, van Riper C, Paxton KL, Kelly JF. Landbird migration in the American west: recent progress and future research directions. Condor. 2009;111:211-25.

5. Marra PP, Cohen EB, Loss SR, Rutter JE, Tonra CM. A call for full annual cycle research in animal ecology. Biol Lett. 2015;11:20150552.

6. Marra PP, Holberton RL. Corticosterone levels as indicators of habitat quality: effects of habitat segregation in a migratory bird during the non-breeding season. Oecologia. 1998:116:284-92.

7. Webster MS, Peter P, Haig SM, Bensch S, Holmes RT, Webster MS, et al. Links between worlds: unraveling migratory connectivity. Trends Ecol Evol. 2002 17:76-83.

8. Faaborg J, Holmes RT, Anders AD, Bildstein KL, Dugger KM, Gauthreaux SA et al. Conserving migratory land birds in the New World: do we know enough? Ecol Appl. 2010;20:398-418.

9. Boulet $M$, Norris RD. Introduction: the past and present of migratory connectivity. Ornithol Monogr. 2006;61:1-13.

10. Finch T, Butler SJ, Franco AMA, Cresswell W. Low migratory connectivity is common in long-distance migrant birds. J Anim Ecol. 2017;86:662-73.

11. DeSante DF, Nott MP, Kaschube DR. Monitoring, modeling And management: why base avian monitoring on vital rates and how should it be done? USDA Forest Service Gen. Tech. Rep. PSW-GTR-19; 2005.

12. Saracco JF, Desante DF, Kaschube DR. Assessing landbird monitoring programs and demographic causes of population trends. J Wildl Manag. 2008;72:1665-73.

13. Ryder TB, Fox JW, Marra PP. Estimating migratory connectivity of gray catbirds (Dumetella carolinensis) using geolocator and mark-recapture data. Auk. 2011;128:448-53.

14. IUCN. Dumetella carolinensis. Data downloaded on December 16, 2016 [Internet]. 2016. Available from: www.iucnredlist.org. Accessed 16 Dec 2016.

15. Woodrey MS, Moore FR. Age-related differences in the stopover of fall landbird migrants on the coast of Alabama. Auk. 1997;114:695-707.
16. Vermeer K. Comparison of white pelican recoveries from colonies east and west of the Canadian rocky mountains. Murrelet. 1977:58:79-82

17. Toews DPL, Heavyside J, Irwin DE. Linking the wintering and breeding grounds of warblers along the Pacific flyway. Ecol Evol. 2017;7:6649-58.

18. Knight SM, Bradley DW, Clark RG, Gow EA, Bélisle M, Berzins LL, et al. Constructing and evaluating a continent-wide migratory songbird network across the annual cycle. Ecol Monogr. 2018;88:445-60.

19. Lisovski S, Németh Z, Wingfield JC, Krause JS, Hobson KA, Seavy NE, et al. Migration pattern of Gambel's white-crowned sparrow along the Pacific flyway. J Ornithol [internet]. Springer Berlin Heidelberg; 2019;160:1097-107. Available from: http://link.springer.com/https://doi.org/10.1007/s10336-019-01685-4

20. Delmore KE, Fox JW, Irwin DE. Dramatic intraspecific differences in migratory routes, stopover sites and wintering areas, revealed using lightlevel geolocators. Proc R Soc B Biol Sci. 2012;279:4582-9.

21. Hobson KA, Kardynal KJ, Van Wilgenburg SL, Albrecht G, Salvadori A Cadman MD, et al. A Continent-Wide Migratory Divide in North American Breeding Barn Swallows (Hirundo rustica). Brigham RM, editor. PLoS One [Internet]. 2015;10:e0129340. Available from: https://dx.plos.org/https://doi. org/10.1371/journal.pone.0129340

22. Kardynal KJ, Hobson KA. The pull of the central flyway? Veeries breeding in western Canada migrate using an ancestral eastern route. J F Ornithol [Internet]. 2017;88:262-273. Available from: http://doi.wiley.com/https://doi. org/10.1111/jofo.12207

23. Phillips AR, Marshall JT Jr, Monson GB. The birds of Arizona. Tuscon, Arizona: University of Arizona Press; 1964

24. Garcia-Perez B, Hobson KA. A multi-isotope $(\delta 2 \mathrm{H}, \delta 13 \mathrm{C}, \delta 15 \mathrm{~N})$ approach to establishing migratory connectivity of barn swallow (Hirundo rustica). Ecosphere. 2014:5:1-12.

25. Pyle P. Identification guide to north American birds - part I. Bolinas, California: Slate Creek Press; 1997.

26. British Antarctic Survey and Biotrack. Light-level geolocators: M-Series geolocator models [Internet]. 2012. Available from: http://www.birdtracker. co.uk/geolocators_2.html. Accessed 7 Apr 2020.

27. Lotek Wireless Inc. PinPoint GPS store-on-board loggers [Internet]. 2020. Available from: https://www.lotek.com/products/pinpoint-gps. Accessed 7 Apr2020.

28. Rappole $\mathrm{JH}$, Tipton AR. New harness design for attachment of radio transmitters to small passerines. J F Ornithol. 1991;62:335-7.

29. Bridge ES, Kelly JF, Contina A, Gabrielson RM, MacCurdy RB, Winkler DW Advances in tracking small migratory birds: a technical review of light-level geolocation. J F Ornithol [Internet] 2013;84:121-137. Available from: http:// doi.wiley.com/https://doi.org/10.1111/jofo.12011

30. Helms JA, Godfrey AP, Ames T, Bridge ES. Predator foraging altitudes reveal the structure of aerial insect communities. Sci Rep Nature Publishing Group. 2016:6:1-10.

31. Care Canadian Council on Animal. Species-specifc recommendation on: Birds. 2008

32. Geen GR, Robinson RA, Baillie SR. Effects of tracking devices on individual birds - a review of the evidence. J Avian Biol. 2019;50:1-13.

33. Lotek Wireless Inc. PinPoint Host User Manual, rev. 10. PinPoint Host Application for PinPoint GPS Tags. 2018

34. Biotrack Limited. M-series geolocator user manual. Wareham, Dorset, United Kingdom: Biotrack; 2013.

35. R Core Team. R: A language and environment for statistical computing [Internet]. R Found. Stat. Comput. Vienna, Austria. 2018. Available from: https://www.r-project.org/. Acccessed 8 Nov 2020

36. Lisovski S, Bauer S, Briedis M, Davidson SC, Dhanjal-Adams KL, Hallworth MT, et al. Light-level geolocator analyses: a user's guide. J Anim Ecol. 2020;89: 221-36.

37. Lisovski S, Hahn S. Geo light - processing and analysing light-based geolocator data in R. Methods Ecol Evol. 2012;3:1055-9.

38. Lisovski SS, Wotherspoon SJ, Sumner MD. TwGeos: Basic data processing for light-level geolocation archival tags. R package version 0.1.2. 2016

39. Calenge $\mathrm{C}$. The package "adehabitat" for the R software: a tool for the analysis of space and habitat use by animals. Ecol Model. 2006;197:516-9.

40. Smith RJ, Hatch MI, Cimprich DA, Moore FR. Gray Catbird (Dumetella carolinensis), version 1.0. In: Poole AF, editor. Birds of the World [Internet]. Ithaca, New York: Cornell Lab of Ornithology; 2020. Available from: https:// doi.org/https://doi.org/10.2173/bow.grycat.01.

41. Hill RD, Braun MJ. Geolocation by light level. The next step: latitude. In: Sibert JR, Nielsen JL, editors. Electron Tagging Track Mar Fish. Dordrecht Netherlands: Springer; 2001. p. 315-30. 
42. Ekstrom PA. An advance in geolocation by light. Mem Natl Inst Polar Res Spec Issue. 2004;58:210-26.

43. Lisovski S, Hewson CM, Klaassen RHG, Korner-Nievergelt F, Kristensen MW, Hahn S. Geolocation by light: accuracy and precision affected by environmental factors. Methods Ecol Evol. 2012;3:603-12.

44. ESRI. ArcGIS Desktop 10.7.1 [Internet]. Redlands, CA Environ. Syst. Res. Inst. Redlands, CA: Environmental Systems Research Institute; 2019. Available from: www.esri.com.

45. Mantel N. The detection of disease clustering and a generalized regression approach. Cancer Res. 1967;27:209-20.

46. Ambrosini R, Møller AP, Saino N. A quantitative measure of migratory connectivity. J Theor Biol. 2009;257:203-11.

47. Nychka D, Furrer R, Paige J, Sain S. Fields: Tools for spatial data. [Internet]. R package version 9.8.6; 2017. Available from: https://github.com/NCAR/Fields.

48. Dray S, Dufour A-B. The ade4 package: implementing the duality diagram for ecologists. J Stat Softw. 2007;22:1-20.

49. DeSante DF, Burton KM, Velez P, Froehlich D, Kaschube D, Albert S. MAPS Manual: 2020 protocol. Point Reyes Station, California: The Institute for Bird Populations; 2020.

50. Laake JL. RMark: an interface for analyses of capture-recapture data with MARK. ASFSC Processed Report. 2013-01. [Internet]. Seattle, Washington; 2013. Available from: https://archive.fisheries.noaa.gov/afsc/Publications/ ProcRpt/PR2013-01.pdf.

51. Cormack RM. Estimates of survival from the sighting of marked animals. Biometrika. 1964:51:429-38.

52. Schwarz CJ. The jolly-Seber model: more than just abundance. J Agric Biol Environ Stat. 2001;6:195-205.

53. Pradel R, Hines JE, Lebreton J-D, Nichols JD. Capture-recapture survival models taking account of transients. Biometrics. 1997;53:60-72.

54. Cooch EG, White GC. Program MARK - A Gentle Introduction (13th edition). 2008;1-1014.

55. Burnham KP, Anderson DR. Model selection and multimodel inference: a practical information-theoretic approach. 2nd ed. New York, New York. Springer-Verlag; 2002.

56. Bairlein F, Norris DR, Nagel R, Bulte M, Voigt CC, Fox JW, et al. Crosshemisphere migration of a $25 \mathrm{~g}$ songbird. Biol Lett. 2012;8:505-7.

57. Battley PF, Warnock N, Tibbitts TL, Gill RE, Piersma T, Hassell CJ, et al. Contrasting extreme long-distance migration patterns in bar-tailed godwits Limosa lapponica. J Avian Biol. 2012;43:21-32.

58. DeLuca W, Woodworth BK, Mackenzie SA, Newman AEM, Cooke HA Phillips LM, et al. A boreal songbird's 20,000 km migration across North America and the Atlantic Ocean. Ecology. 2019;100:1-4.

59. Ruegg KC, Smith TB. Not as the crow flies: a historical explanation for circuitous migration in Swainson's thrush (Catharus ustulatus). Proc R Soc London Ser B Biol Sci. 2002;269:1375-81.

60. Newton I. The migration ecology of birds. Burlington, Massachusetts: Academic Press; 2006.

61. Nickell WP. Habitats, territory, and nesting of the catbird. Am Midl Nat. 1965; 73:433-78.

62. Naiman RJ, Decamps H. The ecology of interfaces: riparian zones. Annu Rev Ecol Syst. 1997;28:621-58.

63. Strong TR, Bock CE. Bird species distribution patterns in riparian habitats in southeastern Arizona. Condor. 1990;92:866-85.

64. Commission for Environmental Cooperation. Ecological regions of North America: toward a common perspective. Montreal, Quebec: Commission for Environmental Cooperation; 1997

65. Heckscher CM, Taylor SM, Fox JW, Afanesyev V. Veery (Catharus fuscescens) wintering locations, migratory connectivity, and a revision of its winter range using geolocator technology. Auk. 2011;128:531-42.

66. Wolfe JD, Johnson El. Geolocator reveals migratory and winter movements of a prothonotary warbler. J F Ornithol. 2015;86:238-43.

67. Cormier RL, Humple DL, Gardali T, Seavy NE. Light-level geolocators reveal strong migratory connectivity and within-winter movements for a coastal California Swainson's thrush (Catharus ustulatus) population. Auk. 2013;130: 283-90

68. Desante DF, Sillett TS, Siegel RB, Saracco JF, Romo CA, Alvarez DV, et al. MoSI (Monitoreo de Sobrevivencia Invernal): assessing habitat-specific overwintering survival of neotropical migratory landbirds. USDA Forest Service Gen. Tech. Rep. PSW-GTR-191; 2005
69. Desante DF, Saracco JF. MoSI (Monitoreo de Sobrevivencia Invernal) manual. Instructions for establishing and operation bird-banding stations as part of the MoSI program. Point Reyes, California: The Institute for Bird Populations; 2009.

70. Hobson KA, Van Wilgenburg SL, Faaborg J, Toms JD, Rengifo C, Sosa AL et al. Connecting breeding and wintering grounds of Neotropical migrant songbirds using stable hydrogen isotopes: a call for an isotopic atlas of migratory connectivity. J F Ornithol [Internet] 2014;85:237-257. Available from: http://doi.wiley.com/https://doi.org/10.1111/jofo.12065

71. Saracco JF, DeSante DF, Nott MP, Kaschube DR. Using the MAPS and MoS programs to monitor landbirds and inform conservation. Proc Fourth Int Partners Flight Conf Tundra to Trop. McAllen, Texas: Partners in Flight; 2005. p. 651-8.

72. DeSante DF, Kaschube DR, Saracco JF. Vital rates of north American Landbirds [internet]. 2015. Available from: www.VitalRatesOfNorthAmerica nLandbirds.org.

73. Darley JA, Scott DM, Taylor NK. Effects of age, sex, and breeding success on site fidelity of gray catbirds. Bird-Banding. 1977;48:145-51.

74. Evans BS, Ryder TB, Reitsma R, Hurlbert AH, Marra PP. Characterizing avian survival along a rural-to-urban land use gradient. Ecology. 2015;96:1631-40.

75. Martin TE, Riordan MM, Repin R, Mouton JC, Blake WM. Apparent annual survival estimates of tropical songbirds better reflect life history variation when based on intensive field methods. Glob Ecol Biogeogr. 2017;26:138697.

76. Perry LG, Andersen DC, Reynolds LV, Nelson SM, Shafroth PB. Vulnerability of riparian ecosystems to elevated $\mathrm{CO} 2$ and climate change in arid and semiarid western North America. Glob Chang Biol. 2012;18:821-42.

77. Capon SJ, Chambers LE, Mac Nally R, Naiman RJ, Davies P, Marshall N, et al. Riparian ecosystems in the 21st century: hotspots for climate change adaptation? Ecosystems. 2013;16:359-81.

78. Wilson S, Saracco JF, Krikun R, Flockhart DTT, Godwin CM, Foster KR. Drivers of demographic decline across the annual cycle of a threatened migratory bird. Sci Rep Springer US. 2018:8:1-11.

\section{Publisher's Note}

Springer Nature remains neutral with regard to jurisdictional claims in published maps and institutional affiliations.

Ready to submit your research? Choose BMC and benefit from:

- fast, convenient online submission

- thorough peer review by experienced researchers in your field

- rapid publication on acceptance

- support for research data, including large and complex data types

- gold Open Access which fosters wider collaboration and increased citations

- maximum visibility for your research: over $100 \mathrm{M}$ website views per year

At $\mathrm{BMC}$, research is always in progress.

Learn more biomedcentral.com/submissions 